\title{
Non-invasive detection and quantification of the parasitic ciliate Ichthyophthirius multifiliis by real-time PCR
}

\author{
Olivier Jousson*, Carlo Pretti, Domenica Di Bello, Anna M. Cognetti-Varriale
}

Dipartimento di Patologia Animale, Profilassi e Igiene degli Alimenti, Università di Pisa, Via delle Piagge 2, 56124 Pisa, Italy

\begin{abstract}
The main parasitic threat to freshwater fish is the ciliate Ichthyophthirius multifiliis. We developed a real-time PCR assay using SYBR Green ${ }^{\mathrm{TM}}$ intercalating fluorescent dye for rapid detection and quantification of $I$. multifiliis. This non-invasive assay was based on the quantification of I. multifiliis free-swimming stages from filtered water samples, and thus made it possible to preserve host individuals. An alignment of $18 \mathrm{~S}$ rDNA sequences of $I$. multifiliis and related species of the ciliate order Hymenostomatida was used to design amplification primers specifically targeting the I. multifiliis 18S rDNA gene. Different standard curves consisting of 2-fold serial dilutions of DNA extracted from 20,60, 100 and 1000 I. multifiliis cells were constructed. The assay was able to detect less than 0.5 cell equivalent and showed a strong linearity $\left(R^{2}=0.984\right)$. Water samples were collected from 2 tanks containing heavily infected and apparently uninfected Carassius auratus specimens and were used to test this technique. Positive signals were obtained from water samples collected from both tanks, with a deduced concentration ranging from 3 to $58 \mathrm{I}$. multifiliis cells $\mathrm{l}^{-1}$. The assay can detect low concentrations of the parasite in water, presumably corresponding to an early phase of the disease. It may, thus, be a valuable tool in assisting in the monitoring and control of ichthyophthiriasis in aquaculture.
\end{abstract}

KEY WORDS: Ichthyophthirius multifiliis · Real-time PCR · Non-invasive assay $\cdot$ Quantification

\section{INTRODUCTION}

The ciliate Ichthyophthirius multifiliis, an economically important parasite in aquaculture and in the ornamental fish trade, is the etiological agent of 'white spot disease', which afflicts a wide range of freshwater fish. Its life-cycle includes a trophont parasitic stage, a tomont reproductive stage, and a theront infective stage. Heavy infections are known to reduce the swimming capacity of the host (Munderle et al. 2004), to favour secondary bacterial infections (Scholz 1999) and to cause considerable mortalities in wild fish populations as well as in cultured hosts (Buchmann et al. 2001). Fishes that survive exposure to I. multifiliis infection acquire protective immunity to subsequent challenge (Dickerson \& Clark 1998, Wang \& Dickerson 2002). These observations indicate that vaccination with I. multifiliis preparations is promising (Ling et al. 1993), although this method is restricted by the difficulties of cultivating this obligate parasite in vitro. Recombinant vaccines (He et al. 1997, Lin et al. 2002) have also been developed, but the immune mechanisms involved in host responses have not been fully elucidated. To date, the control of the disease is mainly based on the use of chemicals such as formalin, copper sulphate, and potassium permanganate (Scholz 1999).

Ichthyophthirius multifiliis infections are classically identified by the presence of trophonts on host skin epithelium. Occasionally, however, the parasite only infects the gills and hence there are no obvious gross lesions on the body surface. As the disease progresses, fish may also show signs of irritation, flashing, weakness, loss of appetite, and decreased activity. Therefore, visual observations only allow identification of 
late phases of the disease. The development of rapid, highly-sensitive diagnostic tests to identify early phases of $I$. multifiliis infections may be useful to assist in the monitoring and control of this pathogen in cultured and ornamental fish. Indeed, a heavy parasite load constitutes an important stress factor for fishes, which may not survive chemical treatments. PCRbased methods have been widely used for disease diagnostic in veterinary parasitology (Zarlenga \& Higgins 2001). Real-time fluorescence-based PCR offers all advantages of conventional PCR, such as high specificity and sensitivity, and also allows for quantification of the PCR product formation during the exponential phase of the reaction. This technique has been used for quantification in infected host tissues of parasitic protozoans such as Plasmodium falciparum (Bell \& Ranford-Cartwright 2004), Toxoplasma gondii (Jauregui et al. 2001), and Neospora Caninum (CollantesFernandez et al. 2002), with a detection limit ranging from 1 to 10 parasite cells.

In this study, we developed a non-invasive real-time PCR assay using SYBR Green ${ }^{\mathrm{TM}}$ intercalating fluorescent dye for detection and quantification of Ichthyophthirius multifiliis. The quantification of free-swimming stages from filtered water samples allowed us to preserve host individuals. Based on previously published 18S rDNA sequences of different species of the ciliate order Hymenostomatida (Wright \& Lynn 1995), primers targeting specifically $I$. multifiliis $18 \mathrm{~S}$ rDNA were designed.

\section{MATERIALS AND METHODS}

Sample collection and DNA extraction. A total of 16 Carassius auratus (Cyprinidae) specimens with a length ranging from 4 to $12 \mathrm{~cm}$ were purchased from several aquarium shops in the province of Pisa (Italy). Four fishes showing obvious signs of Ichthyophthirius multifiliis infection were reared in a tank separated from apparently uninfected fishes (12 individuals). The fishes were preliminary maintained for $2 \mathrm{~d}$ in $60 \mathrm{l}$ tanks at $20^{\circ} \mathrm{C}$. Gills and skin epithelium samples from one heavily infected individual and from 3 apparently uninfected individuals were examined using a stereomicroscope to isolate trophont stages of the parasite. For standard curve construction, I. multifiliis trophonts were isolated, numbered, and DNA from various numbers of cells was extracted in guanidine lysis buffer (Sambrook et al. 1989), precipitated with isopropanol and dissolved in deionised water. Eight water samples ranging from 100 to $1250 \mathrm{ml}$ were collected at the same time from each aquarium. We attempted to obtain only the free-swimming stages of I. multifiliis (non-encysted tomonts or theronts) by avoiding collecting water from the bottom or near the walls of the aquaria, where encysted tomonts might be attached. Two $200 \mathrm{ml}$ samples of distilled water were used as negative controls for real-time PCR. The water samples were filtered through $0.45 \mu \mathrm{m}$ membrane filters (Millipore), and total DNA was extracted using the same protocol as for I. multifiliis cells. DNA quality was checked by $1 \%$ agarose gel electrophoresis. DNA was quantified spectrophotometrically at $260 \mathrm{~nm}$, as well as by using a PicoGreen dsDNA Quantitation Kit (Molecular Probes) and a fluorometer TBS-380 (Turner Biosystems).

Primer design. An alignment of $18 \mathrm{~S}$ rDNA sequences of Ichthyophthirius multifiliis (GenBank accession number U17354) and related species of the ciliate order Hymenostomatida (Wright \& Lynn 1995) was performed using BioEdit software (Hall 1999). The alignment included sequences of Ophryoglena catenula (U17355), Glaucoma chattoni (X56533), Colpidium camphylum (X56532), Tetrahymena australis (M98015), T. tropicalis (M98023), T. thermophila (X56165) and Lambornella sp. (AF364043). To amplify specifically I. multifiliis rDNA, the reverse amplification primer was designed in the most variable part of the alignment (nucleotide positions 631 to 666 in $I$. multifiliis sequence). The software Primer Premier 5.0 (Premier Biosoft International) was used to design primers minimizing the likelihood of the formation of primer-dimers. The forward primer IMRf1 (5'AGTGACAAGAAATAGCAAGCCAGGAG-3') and reverse primer IMRr1 (5'-ACCCAGCTAAATAGGCAGAAGTTCAA-3') located at positions 455 and 647 of I. multifiliis $18 \mathrm{~S}$ sequence, respectively, were selected. In order to confirm the primer specificity, we attempted to amplify DNA from $T$. thermophila strain CCAP 1630/1M and T. pyriformis CCAP 1630/1W kindly provided by F. Dini (University of Pisa). Additionally, we used BLAST to search the GenBank database for published sequences similar or identical to the primers IMRf1 and IMRr1.

Real-time quantitative PCR assays. Real-time PCRs were carried out in an iCycler (BioRad). The $25 \mu \mathrm{l}$ reactions contained $0.3 \mu \mathrm{M}$ of each primer, $12.5 \mu \mathrm{l}$ of $2 \times$ QuantiTect SYBR green PCR master mix, including HotStar Taq DNA Polymerase, SYBR Green PCR Buffer, dNTP mix, SYBR Green I and ROX fluorescent dyes (Qiagen), $1 \mu \mathrm{l}$ of diluted template DNA and $9.5 \mu \mathrm{l}$ of RNAse-free water. The following quantification cycling protocol was used: $2 \mathrm{~min}$ at $50^{\circ} \mathrm{C}$ for carryover prevention, $15 \mathrm{~min}$ at $95^{\circ} \mathrm{C}$ for enzyme activation, followed by 35 cycles of $15 \mathrm{~s}$ at $94^{\circ} \mathrm{C}, 30 \mathrm{~s}$ at $58^{\circ} \mathrm{C}$, and $30 \mathrm{~s}$ at $72^{\circ} \mathrm{C}$ for denaturation, annealing and extension steps, respectively. Fluorescence produced by the binding of the SYBR green fluorochrome to doublestranded (ds) DNA was measured at the end of each extension step. A melting curve analysis was per- 
formed to verify the specificity and identity of the PCR products. It consisted of an additional step from 55 to $95^{\circ} \mathrm{C}$ in increments of $0.5^{\circ} \mathrm{C}$ every $10 \mathrm{~s}\left(0.05^{\circ} \mathrm{C} \mathrm{s}^{-1}\right)$. Several standard curves were constructed with 2 -fold serial dilutions of DNA extracted from 20,60, 100 and 1000 I. multifiliis specimens. Each PCR included the selected standard curve, a negative control (distilled water sample), and a no-template control. Experiments were performed with duplicates for each water sample and with triplicates for each standard curve point.

\section{RESULTS}

The microscopic observation of gill and skin epithelium from 3 apparently uninfected fishes did not reveal any Ichthyophthirius multifiliis cells, whereas the examination of a heavily contaminated Carassius auratus specimen revealed the occurrence of several hundreds of trophonts possessing the characteristic horseshoe-shaped macronucleus of $I$. multifiliis. These cells were isolated and numbered, and DNA was extracted from 20, 60, 100 and 1000 trophonts. Several real-time PCR experiments were performed using 4 different standard curves consisting of 2-fold serial dilutions of I. multifiliis total DNA previously extracted from trophont stages. These standard curves matched well, indicating equivalent efficiencies in DNA extraction (data not shown). The preliminary results obtained from the real-time PCR analysis of water samples revealed that the 60 cells standard was the most appropriate to quantify the samples. Therefore, an 8-point standard curve consisting of 2-fold serial dilutions of the 60 cells standard was selected. The dynamic range was from 0.47 to 60 cells (Table 1). A strong linear relationship between the Ct (cycle threshold) and the log of cell number was observed (correlation coefficient $\mathrm{R}^{2}$ $>0.98$ ) (Fig. 1). The efficiency of the reaction ranged from $80 \%$ to $90 \%$. The assay was sensitive enough to detect DNA from a single I. multifiliis cell-equivalent in less than 27 cycles (Table 1). In the tank containing

Table 1. Serial dilutions and cycle threshold (Ct) values of the 60 cells DNA sample used for standard curve construction

\begin{tabular}{|lccr|}
\hline Sample & Dilution & $\begin{array}{c}\text { Number } \\
\text { of cells }\end{array}$ & Ct (mean \pm SD) \\
\hline St1 & None & 60 & $19.2 \pm 0.02$ \\
St2 & $2 \times$ & 30 & $20.82 \pm 0.45$ \\
St3 & $4 \times$ & 15 & $21.75 \pm 0.23$ \\
St4 & $8 \times$ & 7.5 & $23.59 \pm 0.43$ \\
St5 & $16 \times$ & 3.75 & $24.63 \pm 0.37$ \\
St6 & $32 \times$ & 1.88 & $25.94 \pm 0.23$ \\
St7 & $64 \times$ & 0.94 & $26.32 \pm 0.39$ \\
St8 & $128 \times$ & 0.47 & $27.51 \pm 0.32$ \\
\hline
\end{tabular}

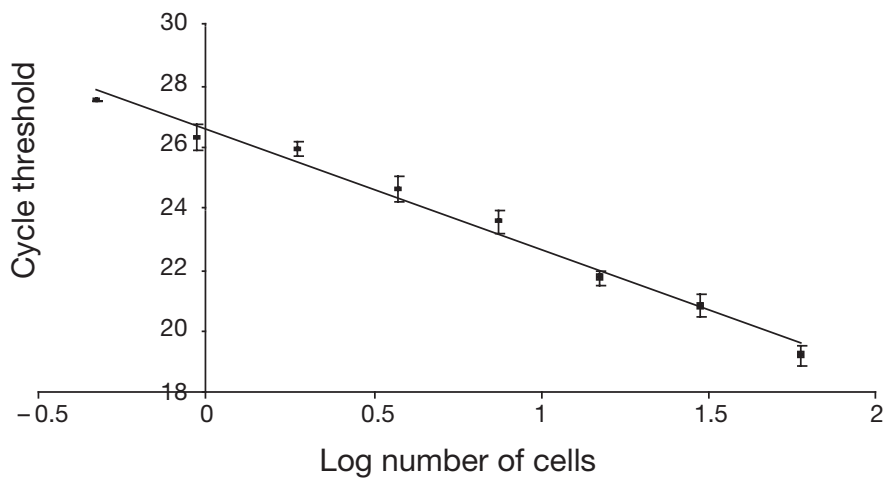

Fig. 1. Calibration curve plotting log number of cells versus cycle threshold $(\mathrm{Ct})$. Variability is shown as mean $\mathrm{Ct}$ values \pm SD. Slope: -3.825 ; intercept: 26.549; correlation coefficient $\left(R^{2}\right): 0.984$

heavily contaminated fishes, I. multifiliis concentration

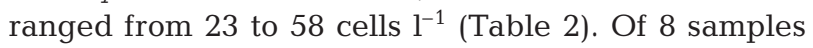
collected from the tank containing apparently uninfected fishes, 2 (Aq2c3 and Aq2c6) did not generate any fluorescence signal and likely did not contain any I. multifiliis cell. The remaining samples revealed a parasite concentration ranging from 3 to 10 cells $\mathrm{l}^{-1}$.

PCR amplifications performed on Tetrahymena thermophila and T. pyriformis DNA to test the specificity of the primers did not reveal any amplification product. BLAST searches using IMRf1 and IMRr1 primer sequences as a query revealed that IMRr1 sequences occur only in Ichthyophthirius multifiliis 18S rDNA. The primers were also tested by conventional PCR on several I. multifiliis DNA extractions. Because SYBR green is a fluorescent dsDNA intercalating dye, it was important to avoid formation of unspecific PCR products and primer-dimers. This was confirmed by electrophoresis of PCR products on $1.5 \%$ agarose gel. A single band at the expected size of $190 \mathrm{bp}$ was observed (data not shown). Additionally, the dissociation protocol included in each real-time PCR experiment revealed that the melting temperature of the PCR product was $82^{\circ} \mathrm{C}$, in agreement with the theoretical value calculated by using Primer Premier 5.0 software. The occurrence of a single fluorescence peak in the melting curve analysis confirmed that no unspecific amplicons or primer-dimers were formed during PCR.

\section{DISCUSSION}

The non-invasive real-time PCR assay developed in this study has shown to be specific and sensitive for detection and quantification of Ichthyophthirius multifiliis free-swimming stages from water samples. It detected less than 0.47 cell-equivalent and was therefore capable of diagnosing early phases of the 
Table 2. Ichthyophthirius multifiliis. Quantification of $I$. multifiliis cells from water samples. Tanks 1 and 2 contained 4 heavily infected and 12 apparently uninfected Carassius auratus, respectively. Ct: cycle threshold. Values are means $\pm \mathrm{SD}$

\begin{tabular}{|cccccc|}
\hline Sample & Tank & Ct & $\begin{array}{c}\text { I. multifiliis } \\
\text { cell }\end{array}$ & $\begin{array}{c}\text { Volume of water } \\
\text { filtered }(\mathrm{ml})\end{array}$ & $\begin{array}{c}\text { I. multifiliis } \\
\text { cells }{ }^{-1}\end{array}$ \\
\hline Aq1c1 & 1 & $23.66 \pm 0.35$ & $5.8 \pm 1.19$ & 250 & $23.0 \pm 4.81$ \\
Aq1c2 & 1 & $20.89 \pm 0.25$ & $30.4 \pm 4.95$ & 1250 & $24.3 \pm 3.96$ \\
Aq1c3 & 1 & $23.27 \pm 0.25$ & $7.3 \pm 1.06$ & 125 & $58.0 \pm 8.49$ \\
Aq1c4 & 1 & $24.62 \pm 0.16$ & $3.2 \pm 0.28$ & 100 & $32.0 \pm 2.83$ \\
Aq1c5 & 1 & $24.17 \pm 0.26$ & $4.2 \pm 0.71$ & 100 & $42.0 \pm 7.07$ \\
Aq1c6 & 1 & $22.31 \pm 0.23$ & $12.9 \pm 1.69$ & 250 & $51.6 \pm 6.79$ \\
Aq1c7 & 1 & $23.84 \pm 0.42$ & $5.2 \pm 1.27$ & 150 & $34.7 \pm 8.49$ \\
Aq1c8 & 1 & $23.27 \pm 0.31$ & $7.3 \pm 1.34$ & 150 & $48.4 \pm 8.98$ \\
Aq2c1 & 2 & $25.32 \pm 0.14$ & $2.1 \pm 0.14$ & 250 & $8.4 \pm 0.57$ \\
Aq2c2 & 2 & $26.25 \pm 0.29$ & $1.3 \pm 0.21$ & 250 & $5.0 \pm 0.85$ \\
Aq2c3 & 2 & No signal & - & 100 & - \\
Aq2c4 & 2 & $24.57 \pm 0.51$ & $3.4 \pm 0.99$ & 1000 & $3.4 \pm 0.99$ \\
Aq2c5 & 2 & $26.72 \pm 0.57$ & $0.9 \pm 0.28$ & 150 & $6.0 \pm 1.84$ \\
Aq2c6 & 2 & No signal & - & 150 & - \\
Aq2c7 & 2 & $23.98 \pm 0.48$ & $4.8 \pm 1.41$ & 500 & $9.6 \pm 2.82$ \\
Aq2c8 & 2 & $24.84 \pm 0.18$ & $2.8 \pm 0.28$ & 500 & $5.6 \pm 0.57$ \\
\hline
\end{tabular}

disease. The experiments showed acceptable values of standard error for the quantification of cells in a given sample (Table 2), confirming the reproducibility of the assay. Ribosomal DNA genes are of particular interest for the development of highly sensitive real-time PCR assays because they are usually present in a high number of copies in eukaryotes, and thus provide an appreciable number of target sequences for PCR. The number of gene copies is typically used as a standard curve unit in real-time PCR experiments and can provide a rough estimate of the number of organisms if the number of copies per genome is known. Since the number of rDNA genes has not been yet identified in $I$. multifiliis, we attempted to construct standard curves based on the number of cells. This was possible because of the high number of parasite cells that could be found on a single heavily infected host. The use of DNA extracted from 60 cells for construction of the standard curve was justified by the fact that the most concentrated filtered water sample (Aq1c2) contained approximately 30 cells. It is likely that much higher values of parasite concentration in water may be obtained from aquaria containing heavily infected hosts. This may depend on the relative number of encysted, substrate-attached tomonts versus freeswimming tomonts or theronts at the time sampling is performed. For the quantification of potentially more concentrated samples, I. multifiliis DNA extracted from 100 or 1000 cells might be used for the construction of standard curves as it has a higher dynamic range.
Until a vaccine using Ichthyophthirius multifiliis preparations or recombinant DNA technology has been developed, the main way to control the disease to date is chemotherapy. The treatment of ichthyophthiriosis can be difficult because only free-swimming tomonts or theronts are susceptible to chemical treatments. Indeed, the encysted tomont and the trophont are protected from most agents that are added to the water (Woo 1995). Therefore, the application of a single treatment will only kill free-swimming tomonts or theronts which have emerged from cysts and have not yet penetrated into the skin of host fish. The treatment should thus be repeated at regular time intervals to continually break the cycle of infection until the epizootic is controlled. Given that the life-cycle of I. multifiliis is strongly temperature-dependent (Aihua \& Buchmann 2001), the determination of the most appropriate time intervals between treatments is not easy. The present assay may be used to survey the life-cycle dynamic of $I$. multifiliis and to determine at which time intervals the concentration of theront stages is the highest, therefore optimizing the treatment procedures. This reliable and early diagnostic test enabling the application of adequate treatment to prevent serious outbreaks may be helpful for an effective control of I. multifiliiis in cultured and ornamental fish.

Acknowledgements. This work was supported by a grant from the Italian Ministry of Instruction, University and Research (MIUR). We thank M. Mazzei for his help in optimizing real-time PCR experiments and P. Famà for critical review of the manuscript.

\section{LITERATURE CITED}

Aihua L, Buchmann K (2001) Temperature- and salinitydependent development of a Nordic strain of Ichthyophthirius multifiliis from rainbow trout. J Appl Ichthyol 17: 273-276

Bell AS, Ranford-Cartwright LC (2004) A real-time PCR assay for quantifying Plasmodium falciparum infections in the mosquito vector. Int J Parasitol 34:795-802

Buchmann K, Sigh J, Nielsen CV, Dalgaard M (2001) Host responses against the fish parasitizing ciliate Ichthyophthirius multifiliis. Vet Parasitol 100:105-116

Collantes-Fernandez E，Zaballos A, Alvarez-Garcia G, Ortega-Mora LM (2002) Quantitative detection of Neospora caninum in bovine aborted fetuses and experimentally infected mice by real-time PCR. J Clin Microbiol 40:1194-1198

Dickerson H, Clark T (1998) Ichthyophthirius multifiliis: a 
model of cutaneous infection and immunity in fishes. Immunol Rev 166:377-384

Hall TA (1999) BioEdit: a user-friendly biological sequence alignment editor and analysis program for Windows 95/98/NT. Nucleic Acids Symp Ser 41:95-98

He J, Yin Z, Xu G, Gong Z, Lam TJ, Sin YM (1997) Protection of goldfish against Ichthyophthirius multifiliis by immunization with a recombinant vaccine. Aquaculture 158:1-10

Jauregui LH, Higgins J, Zarlenga D, Dubey JP, Lunney JK (2001) Development of a real-time PCR assay for detection of Toxoplasma gondii in pig and mouse tissues. J Clin Microbiol 39:2065-2071

Lin Y, Cheng G, Wang X, Clark TG (2002) The use of synthetic genes for the expression of ciliate proteins in heterologous systems. Gene 288:85-94

Ling KH, Sin YM, Lam TJ (1993) Protection of goldfish against some common ectoparasitic protozoans using Ichthyophthirius multifiliis and Tetrahymena for vaccination. Aquaculture 116:303-314

Munderle M, Sures B, Taraschewski H (2004) Influence of

Editorial responsibility: Wolfgang Körting,

Hannover, Germany
Anguillicola crassus (Nematoda) and Ichthyophthirius multifiliis (Ciliophora) on swimming activity of European eel Anguilla anguilla. Dis Aquat Org 60:133-139

Sambrook J, Fritsch EF, Maniatis T (1989) Molecular Cloning: A laboratory manual. Cold Spring Harbor Laboratory Press, Cold Spring Harbor, NY

Scholz T (1999) Parasites in cultured and feral fish. Vet Parasitol 84:317-335

Wang X, Dickerson HW (2002) Surface immobilization antigen of the parasitic ciliate Ichthyophthirius multifiliis elicits protective immunity in channel catfish (Ictalurus punctatus). Clin Diagn Lab Immunol 9:176-181

Woo PTK (1995) Fish diseases and disorders, Vol 1. Protozoan and metazoan infections. CABI Publishing, New York

Wright AD, Lynn DH (1995) Phylogeny of the fish parasite Ichthyophthirius and its relatives Ophryoglena and Tetrahymena (Ciliophora, Hymenostomatia) inferred from 18S ribosomal RNA sequences. Mol Biol Evol 12:285-290

Zarlenga DS, Higgins J (2001) PCR as a diagnostic and quantitative technique in veterinary parasitology. Vet Parasitol 101:215-230

Submitted: January 21, 2005; Accepted: March 3, 2005

Proofs received from author(s): June 27, 2005 